\title{
Structural Genocide and Institutionalized Racism in Canada: The Department of Indian Affairs and Framing of Indigenous Peoples
}

Laura Mudde ${ }^{1,2}$

${ }^{1}$ Exchange program 2015 University of Alberta, Edmonton, 116 St \& 85 Avenue, Edmonton, Alberta, Canada

${ }^{2}$ For the partial completion of M.A. degree 2016 in North American Studies in the International Relations Department at Utrecht University Domplein 29, 3512 JE Utrecht, Netherlands

\section{Key points:}

- Marginalization of Indigenous peoples is a continuous process established in the nineteenth and twentieth century bureaucracy of Canada.

-Subjective and racialized historical concepts create health and socio-economic disparities between Indigenous and non-Indigenous groups in Canada.

-Structural genocide more accurately describes the treatment of Indigenous peoples in Canada.

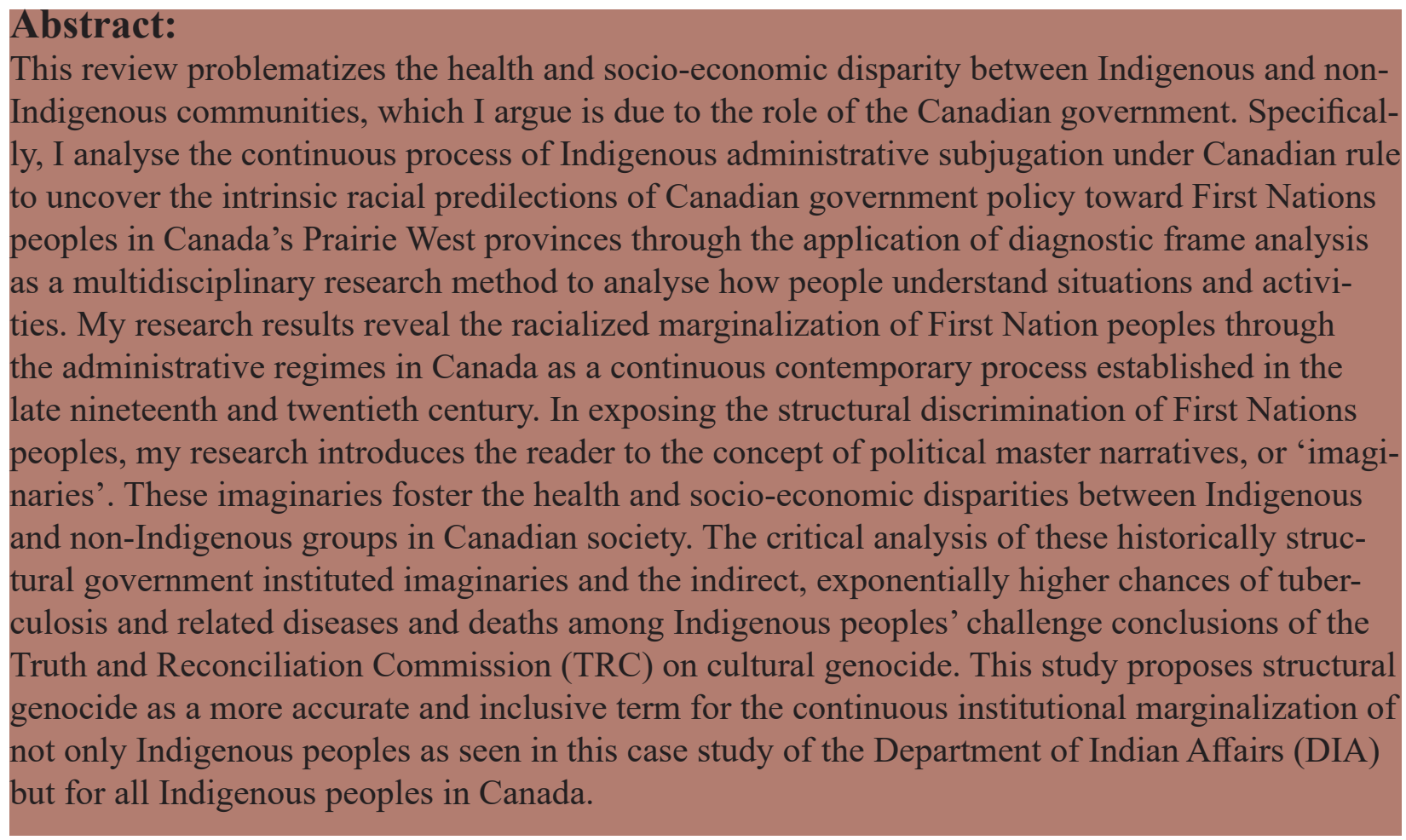

Key words: Canada, Indigenous, government, health, tuberculosis.

Correspondence to: 1.mudde91@gmail.com 


\section{Introduction}

Even though the Canadian government exerts an active health policy against TB and related diseases, Indigenous peoples still experience continuous health disparities relative to non-Indigenous people. An example are the TB rates related to socio-economic disparities under Canadian governance since the 1870s (Henderson and Wakeham 2008). According to the 2013 Canadian Chief Public Health Officer's Report, "the burden of TB in the Aboriginal population is much greater than in the overall population". This is indicated by the much higher rate of TB-related disease on Aboriginal status people compered to non-Aboriginal people (Public Health Agency of Canada [accessed 2013]).

The active Canadian policy, as well as the statistics and expert opinion, postulate a continued disparity between Indigenous and nonIndigenous groups. According to J.W. Daschuk, despite high standards in social welfare, health care, and economic development, most reserves in Canada have "more in common with the Third World" (Daschuk 2013, p. 186). In the case of social welfare, health care, and economic development, TB-related diseases are especially connected to diet and living conditions. This questions the reason for both structurally and exponentially higher death rates among Indigenous groups (Public Health Agency of Canada [accessed 2013]). Moreover, despite past government policies of social welfare, health care, and knowledge regarding treatment and prevention of TB-related diseases since the 1910s, most reserves are still characterized by deteriorating living conditions, enhancing TB incidences among Indigenous peoples.

This study problematizes the historical emergence of socio-economic and health disparities and their connection to TB-related diseases among Indigenous peoples in Canada's Prairie West. I argue that the Canadian colonial government and its consolidation of institutionalized marginalization in regulatory regimes is not a problem solely in the past, but still apparent and problematic in the present. The Canadian Prairie
West. I argue that the Canadian colonial government and its consolidation of institutionalized marginalization in regulatory regimes is not a problem solely in the past, but still apparent and problematic in the present. The Canadian Prairie West refers to the geographic areas of Treaties 1, $2,4,5,6,7$, and 8, which include northern parts of British Columbia but mostly covers parts of Manitoba, Saskatchewan, and Alberta, excluding the Northwest Territories (Aboriginal Affairs and Northern Development Canada [accessed 2018]).

I have analysed the Department of Indian Affairs (DIA) Annual Reports between 1900 and 1915 for racial framing and neglect and discrimination of Indigenous peoples in the Prairie West. In turn, these reports have been connected to the health and socio-economic disparities experienced by Indigenous peoples in Canada today (CBC News [accessed 2016]). My analysis of the reports alludes to the continuities of the imaginaries of colonization of Indigenous peoples by providing an alternative conclusion and addition to the research done by the Truth and Reconciliation Commission (TRC). I argue for the use of the term structural genocide rather than cultural genocide to more accurately describe the continuous institutionalized marginalization experienced by Indigenous peoples. In this context, structural genocide refers to the all-encompassing nature of genocide still going on in Canada's colonial society.

1.1 History of Relations: Canadian Government framing of Indigenous Peoples

The 1870's saw the emergence of an institutional system that categorized the inhabitants of the Canadian Prairie West according to race. According to Canadian historian John S. Milloy and Métis scholar Chris Andersen, today's Aboriginal ancestry and identity originated in the Royal Proclamation of 1763 and the Indian Act of 1876 (Milloy 1999; Andersen 2013). In these documents, the Canadian government and the DIA stipulated who was and was not an "Indian." In turn, the DIA as a political body policed all those defined as "Indian," which was further institutionalized through the signing of treaties with these "Indian" bands, resulting in reserve life and 
subsequent deteriorated living conditions (Milloy 1999; Andersen 2013). Additionally, a census conducted by Health Canada in 2014 was still based on 1763 and 1876 categorizations (Leslie 2002).

The inherent racial biases of these categorizations connect to the political ideology of liberalism, defined as the "extraordinary measures to be employed to remove Indigenous peoples from the territories" to make room for primarily Caucasian immigrants (Smith 2009, p. 2). The political framing of Indigenous peoples by the DIA and government officials guided policy toward Indigenous peoples. The underlying goal of territorial acquisition and liberal capitalist notions of hardwork and self-support were instructive for the limited aid on reserves and the discrepancy between treaty promises and reality (Hildebrandt et al. 1996; Price 1999). These extraordinary measures to remove Indigenous peoples for homesteaders no longer included open warfare or overt "genocide". Nevertheless, the administrative coercion and governmental implementations were no less effective in obtaining territory, or less structural in deteriorating the lives of Indigenous peoples.

The structural character of political imaginaries - perspectives based on subjective and racialized historical concepts lacking critical historical deconstruction - maintained by the Canadian government are continuously met with dissenting voices (Coulthard 2014; Alfred 2005; Simpson 2014; Andersen 2014; Battiste and Henderson 2000; Turner 1998, 2000; Cook-Lynn 1997, 1998; Moreton-Robinson 2003; Nakayama and Krizek 1995). Indigenous critical scholars and scholars from the fields of law and social geography critique the unequal distributions of power and access for minorities in liberal capitalist states, especially in the colonial context (Darden and Kamel 2002; Soja 2010; Harris 1993; Mako 2012; Schabas 2000). The critique of the Canadian government's institutionalized marginalization based on race is increasing in the twenty-first century. DIA political imaginaries communicated an instructive case study to the overt and embedded notions of race and class in connection to living conditions and disease, but they lacked self-critique.
The leading question in relation to this inherent racial bias is how the imaginaries between 1900 and 1915 have a continued legacy within administrative regimes and white normativity. Moreover, this continued institutionalized marginalization suggest the term structural genocide rather than cultural genocide to emphasize the continued structural nature of colonialism in institutional government settings. In this case study, a complex primary frame includes that of scientific racism in connection to class.

This study seeks to answer the question of whether the primary frame substantiated through academic research is visible in the DIA documents or whether its normativity has made its visibility in the documents unnecessary. In relation to structural genocide and the continued disparities between Indigenous peoples and "mainstream" Canada, can policies be blamed if scientific racism was perceived as the natural truth? How does scientific racism within DIA policy between 1900 and 1915 relate to treatment and policy toward Indigenous peoples today if we accept the notion of structural genocide? What does this mean for the continuity of these policies today and the question of institutionalized racism?

\section{Methods}

I analyzed the leading question in relation to this inherent racial bias and how the imaginaries between 1900 and 1915 have a continued legacy within administrative regimes and white normativity. Moreover, this continued institutionalized marginalization justifies the use of the term structural genocide rather than cultural genocide to indicate the continued structural nature of colonialism in institutional government settings. Institutionalized marginalization, through political imaginaries and promulgated with stereotypes, was analysed with the use of critical theory from Indigenous studies, postcolonial studies, social and political science, and history. These fields were combined with the primary source analysis of the DIA's Annual Reports to expand TRC's conclusions 
for cultural genocide. Political imaginaries from a hundred years ago were more than just abstract ideas on race and class, and they became institutionalized in law and governance, which has created structural subjugation of Indigenous peoples. Political imaginaries refer to the predominant perspectives in political circles, especially pertaining to Indigenous peoples and the transfer of those socially constructed perspectives to the public.

The political imaginaries of the Canadian government were analyzed using frame analysis on the public sources closest to DIA policy and ideology. The Annual Reports of the DIA are a public record by which progress and the political objectives of the Canadian government regarding Indigenous peoples are communicated. Diagnostic frame analysis was used as a tool to look at the justification mechanisms for DIA policy toward both themselves and their intended audience. The DIA Annual Reports and the frame analysis function as comparative materials to the historical discourse on Indigenous-governmental relations.

My research focuses on governmental political imaginaries and implications and employs a top-down approach. This analysis is highly onedimensional, at times abstract, and conducted by a non-Indigenous person. Nevertheless, it is necessary to address the issue of structural marginalization and its racial predilections to understand the structural nature of institutionalized racism and the emptiness of terms such as post- or neo-colonialism. Moreover, this research has not incorporated First Nations peoples, but rather focused on the non-Indigenous historical political perspectives and institutionalization by the Institution of Canada. In general, the content is of a critical nature and can be placed within a discourse of activism and critique on liberal capitalist societies' inherent white normativity and lack of introspection.

In doing so, this study is not meant to generalize the experiences of Indigenous peoples. "Indians" is used throughout the text to refer to the way in which the DIA mentions Indigenous peoples. Indigenous is used in the general analysis. When a cited author or paraphrased academic uses capitalized versions or other terms, the origi- nalis copied. Throughout this paper, I have chosen to use the term Indigenous to refer to the communities on reserves and in residential schools during the research period of 1900 to 1915 and in the twenty-first century. It is important to know "Indigenous" as a group are not a homogenous group and the generalizing concepts displayed here are from the perspective of the government actor that does categorize and generalize under the term "Indian". This is not as to repeat this generalization, but to better understand the diagnostic framing done by the DIA and the construct of whiteness.

This study seeks to problematize notions of Canada's great civilization and society and the myth that Canada does not have a colonial past (Reuters 2009). It describes how white normativity is constructed and how this norm and self-image have been ignored or manipulated. The consequences of this whitewashing of minorities are often overlooked, but are recognized by scholars as a mechanism of liberal capitalist governance to homogenize its population (Kelm 1998). Resistance and struggle vary, but are seen throughout all communities, bands or tribes and affected by geographic location and time.

\subsection{Frame Analysis}

Frame analysis is used mostly in the social sciences and comprises a multitude of concepts and perspectives on the ways in which individuals, groups, and societies organize, perceive, and communicate their realities. Framing involves the social constructions of "reality" to make sense of social phenomena. Framing, or the attachment of meaning, is an inevitable process (Goffman 1975). The concept of frame analysis has been widely employed in the past (Goffman 1975; Snow and Benford 1988, 2000; Snow et al. 2007).

In a political context, frames are the packages in which information is presented. Part of the rhetoric is then presented in such a way as to establish or solidify certain interpretations and discourage or denounce others (Goffman 1975). In political framing, facts are often presented to reveal a problem and the corresponding need for specific solutions. Moreover, this information attempts to justify past, present, and future policy 
implementations. Political framing is often manipulated specific to time and place and influenced by power relations and perceptions about objectivity or agency (Froehlich and Rüdiger 2005).

The focus of this study is on the government as distributer of diagnostic frames about Indigenous peoples' health; it is less about the recipient audience or societal response. Nevertheless, the DIA and its framing of Indigenous peoples' health and TB-related diseases on reserves and in residential schools is also influenced by public opinion. To make DIA's policies feasible, the DIA frames had to resonate with the primary frames of the society. A primary frame is how a person (or group) explains and justifies what is happening within its own reality (Goffman 1975). These primary frames are influenced by larger societal norms and values, internal pressures and constraints, and external pressures. For instance, opposition, other policy makers, and ideological orientations, such as liberalist expansionism, influence primary frames (Goffman 1975).

The DIA actively sought to impress its readers and the political opposition in conveying and processing data on the development project as successfully as possible, while exuding a level of objectivity and truthfulness with its members (Smith 2009). Often, information was contextualized to reinforce the DIA's goals and aspirations as they resonated with both the public and government objectives (Russell 1984). The DIA's Annual Reports were meant to shape and satisfy the public's opinion in the same way that the media helps shape mass opinion today. This makes the reports useful for the analysis of political imaginaries about Indigenous minorities in connection to health, race, and class.

According to Canadian sociologist Erving Goffman, the meaning of a frame has certain cultural roots or context dependency (Goffman 1975). Specific to the framing mechanism of the DIA in the Annual Reports is their absolute power within the bureaucratic system, which allowed for intensive policing by individual Indian Agents and surveillance of what would appear in the reports (Smith 2009). This context dependency, according to media scholar Robert M. Entman, has to do with "a scattered conceptualization" and "a frac- tured paradigm" (1993). This means that frames are incomplete for explaining certain phenomena and leave elements up to the readers' interpretation (Entman 1993). In other words, the DIA selected frames of perceived reality and thereafter promoted certain definitions and interpretations that reverberated within the cultural roots or context. Frame analysis thus constitutes an interpretative model (Goffman 1975; Snow and Benford 1988, 2000; Snow et al. 2007). Frames as the "schemata of interpretation" indicate how the $\mathrm{Ca}$ nadian state viewed itself in relation to Indigenous peoples and the public (Goffman 1975). Diagnostic frame analysis most accurately connects political imaginaries to the larger belief-system, as well as the primary frame and its resonance and relevance when creating a justification for government policy (Snow and Benford 2000, p. 197-215).

The stronger a frame and the more it reaffirms a primary frame, the more people accept the policy (Snow and Benford 2000). Diagnostic frames are valuable for their level of success when used to place blame or attach causality, such that an effective use of the frame method can make it possible for the framing party to get away with murder. According to Lakoff, a frame needs to be rhetorical to persuade a political audience of the justification for action or inaction (Lakoff, 2002). The DIA as the framing party can control the perception of the general population of Indigenous peoples by consistently invoking one or more frames (Andersen 2013).

The DIA Annual Reports are part of the "politics of signification" that had serious material and non-material consequences for the treatment of Indigenous peoples by the DIA (Smith 2009, p. 3). The consequences in residential schools were analyzed by the TRC as cultural genocide and would, according to Patrick Wolfe, be categorized as part of the logic of elimination and structural genocide (Wolfe, 2006). Similarly, a diagnostic frame analysis of the DIA Annual Reports on TB-related diseases between 1900 and 1915 in connection to TB-related diseases today problematizes the political imaginaries and makes a case for structural genocide. This review combines both the DIA reports and academic debate to problematize the con- 
ceptualization of cultural and structural genocide.

\section{Critical Analysis of DIA Annual Reports}

According to Canadian historian Bill Russell, the DIA's paper trail gives us more insight in the 1900-1915 period as a form of public memory (Russell 1984, p. 50). These paper archives teach us about policy today as well. The DIA was part of the national time of development in Canada and the "maturation of government institutions" (Smith 2009, p. 93). For the DIA, "it was in these years that an Indian policy defined in the Province of Canada before Confederation was carried East and West into a full national structure" (Smith 2009, p. 93). A significant bureaucracy developed, completely dedicated to policy implementation and refinement. This paper trail gives insight into government perceptions on Indigenous peoples and what it deemed important to communicate to the public.

The DIA was the complete and sole administrative power between 1900 and 1915 when reporting on Indigenous peoples in connection to health treatment and relief. Categorizations of race and class were used uncritically, and these actions institutionalized Indigenous peoples as lesser than the white Euro-Canadian. The lack of foresight-by DIA officials regarding these processes was problematic. The diagnostic frame analysis of the Annual Reports of the DIA between 1900 and 1915 seeks to illuminate the processes of institutionalized racism and how the disparities in health between Indigenous peoples and Euro-Canadians are framed. This is a necessary step to further problematize contemporary notions of the socio-economic health gap between Indigenous and non-Indigenous peoples and the role of the Canadian government in keeping this situation unaltered (Russell 1984, p. 51).

The Canadian government and the DIA were guided by a general moral of administrators centered on efficiency and rationality: "the overriding preoccupation of the Victorian bureaucrat with economy and efficiency in all aspects of de- partmental administration had a major impact on records-keeping operations" (Russell 1984, p. 51). This administrative rationalization, centralization, and the general resistance to change bureaucracy in light of efficiency and economics is what created the DIA's ideology, and consequently formed the ways in which Indigenous peoples were described and policed (Smith 2009).

The DIA saw its records on assimilative progress as part of writing history for future generations. The DIA believed their work had more value than other departments, and its records had to be "kept intact for historical purposes as an example to future generations" (Smith 2009, p. 95-96). One example regarding the value of the DIA's work was its reluctance to dispose of any files. The DIA's chauvinism created the feeling of uniqueness and historical importance (Russell 1984). Historians Smith and Russell agree: "Functionaries of the DIA [...] had a romantic impetus for data collection" (Smith 2009, p. 94).

This chauvinism was guided by the DIA's feeling of responsibility towards its wards, as they perceived a moral and legal responsibility to the "White Man's Burden" (Russell 1984, p. 52). The idea of the "White Man's Burden" in the administrative body of the DIA had consequences for its subjects, especially since the DIA was responsible for all aspects of "Indian life" between 1860 and 1914. The length and the number of records created during this time reflect the size and allencompassing nature of the DIA's policy (Russell 1984). The DIA records formed the EuroCanadian version of written history on peoples.

According to Canadian anthropologist Noel Dyck, the DIA's coercive administration can be defined as an extreme form of guardianship (Dyck, 1997). This coercive guardianship necessitated extensive record-keeping and was part of an administrative tradition. The provisions of the 1857 Gradual Civilization Act allowed the Euro-Canadian administration to transform racist assumptions about Indigenous peoples into an all-encompassing administrative reality. It needs to be mentioned that these "Indian" categories themselves excluded and continue to exclude many non-status Indigenous 
peoples. Moreover, Indigenous resistance to these coercive policies was substantiated by the DIA as evidence of the lack of development of Indigenous peoples. This absence validated coercive guardianship and policies of assimilation (Smith 2009).

Guardianship, on this scale, warranted extensive paper administration; the DIA records present every aspect of the administration of affairs in a top-down analysis (Smith 2009). Motives for this were record-keeping, intelligence gathering, keeping possible rebellions in check, and containing possible dissatisfaction with the assimilative policies. One of these policies was the rehabilitation project, which meant the forced relocation of Indigenous peoples. According to Smith, the DIA did its best to hush conflicts and was busy maintaining an image of friendly relations and public equality as seen in the model farms on reserves to impress foreign diplomats of the Canadian assimilation project (Carter 1990). Smith (2009) discerns that the diagnostic framing of peoples by the DIA was grounded in the idea of stimulating European migration to Canada and necessitated the pacification of the "Indian". Administrative control successfully minimized public discontent by keeping Indigenous peoples silent and out of sight.

The DIA's control was informed by liberalism and market economics. Liberalism and capitalism created the "structures that continue to oversee the life-threatening material conditions faced by many Indigenous peoples in Canada" (Smith 2009, p. 2). Liberalism in the Canadian prairies justified the measures taken to remove Indigenous peoples from their territories for settler capitalism to develop. This ideology of chauvinism, liberalism, and capitalism is not only an ideological formation of people's lives; the ideology brings forward the framing of Indigenous peoples as second-rate citizens (Smith 2009). The diagnostic frames in the DIA Annual Reports between 1900 and 1915 form a continuous process of Indigenous subjugation to health and socio-economic disparities under capitalist liberalism today.

The DIA initiated this continuous process of excluding Indigenous peoples based upon their dehumanization in the Royal Proclamation and the
Indian Act. According to Smith (2009), Indigenous peoples were treated like children and not considered citizens in Canadian society; thus, they were dehumanized and not protected against state interference. Indigenous peoples' representation became completely dependent on governing structures and DIA data collection, Moreover, the DIA's data collection was prone to sloppiness and manipulation to provide the best portrait of the assimilation project in favour of the DIA and without regard for peoples or their deteriorating living conditions (Smith 2009).

I found examples of the sloppiness of the DIA in the 1909 Annual Reports: "returns as a whole are defective; [...] figures are manifestly defective [and] it may be said that altogether the bands [...] are infected with tuberculosis to an extraordinary degree" (DIA Annual Report 1909, p. 452). This problematizes the death rates mentioned and, in combination with the false entries on reserves in southern Alberta, the Annual Reports lose credibility. According to the same 1909 Report, the incomplete number and sloppiness indicate the real number of TB-related deaths in the year 1909 is much higher. This realization questions the death rates mentioned in the reports and indicates the living conditions and resulting deaths by TB-related diseases on reserves and in residential schools might have been even worse than reported.

In fact, throughout the Annual Reports, a pattern stands out. Some of the entries featured in the Annual Reports appear to be standard entries or sentences copied for each year. One of such entries is: "there are still a number of cases of consumption and scrofula on these reserves, for which but little can be done; otherwise the health of the band has been good. Sanitary precautions have been well attended to, and their houses are kept neat and clean" (DIA Annual Reports 1900-1915). The question remains if this was a general description entry used by Indian Agents and/or the DIA to cover up missing information on Indigenous peoples' well-being, or if the information provided by the Indian agent on the reserve was not in line with DIA policy.

Therefore, the DIA's Annual Reports and featured political perceptions, descriptions, and categorizations convey more about the Euro-Cana- 
dian views on the "Indian" than about the actual situation on reserves and in residential schools. The DIA's paper trail is a social and political construct written in accordance with accepted Euro-Canadian diagnostic frames based on liberal capitalist values (Smith 2009). DIA policy was instructed by the image Euro-Canadians themselves had fabricated of non-Euro-Canadians.

This image of First Nations people, or the imaginary constructed between the non-Indigenous and Indigenous peoples by the DIA, was not a fixed boundary. To maintain the exclusionary mechanisms of the administrative system, the boundary was and continues to be flexible through time. The DIA aligned the mechanisms of Indigenous exclusion to public opinion and societal norms and values (Stoler 1995). The archival texts only provide subjective constructs from the dominant and one-sided government structure. Through time, the DIA construct of Indigenous peoples and disease changed in form and language but continued to be exclusionary.

\subsection{DIA's Administrative Bureaucracy and the Case Study on TB}

Beginning in the nineteenth century, the DIA, through various tactics, established administrative regions that institutionalized and organized the supervision and reform of Indigenous peoples in the Prairie West (Smith 2009). The DIA organization had to be present in all aspects of Indigenous lives to assimilate and monitor progress. This meant contact between Indigenous First Nations peoples and the DIA occurred through Indian agents and was monitored by inspectors. These inspectors were supervised by superintendents, or "commissioners", who had to answer to the deputy superintendent general, who then had to report to the cabinet minister, who was also the superintendent general of Indian affairs (Carter 1999). Apart from this bureaucratic pyramid hierarchy, the policy implementers had room to follow their own policy due to the geographic distances and infrequent contact between the different layers of officials.

Even though the different levels in the hierarchy of the DIA policed one another, individuals could be tyrants and expose Indigenous peoples on and off reserves to vile treatment. Moreover, in case of conflict, agents acted as complainant, prosecutor, and presiding judge serving the DIA's interests. In the case of TB, it was the inspectors who had to supervise health and relative development of First Nations peoples on reserves (Smith 2009). Nevertheless, surveillance, tempered by the economy, was more important than agricultural instruction or general living conditions (Smith 2009). As a result, vile treatment could pass unnoticed.

Even though all information collected from reserves and residential schools was analyzed, not everything would make it into the DIA's Annual Report (Smith 2009). For which I suggest that these reports were written to serve the public's approval to make the DIA look credible, rational, and well-informed, but reports were manipulated and dressed up by Indian Agents to meet the demands of the DIA. In attempt to prevent failure, which could discredit the DIA or federal politicians, which might cause unwanted "public scrutiny, and eventually bring DIA objectives and policy into question" (Smith 2009, p. 118). As such, I agree with Smith (2009), in that the DIA policy was part of the Canadian bureaucracy, designed to get rid of Indigenous peoples while simultaneously keeping federal costs low and resistance to a minimum.

\section{Prevailing Diagnostic Frames}

The primary source analysis displayed in Table 1 is indicative of the Canadian bureaucracy between 1900 and 1915. Analysis of the DIA Annual Reports found that the words "tuberculosis", "scrofula", or "consumption" and related spellings, appeared more than 1,805 times on more than 14,400 pages (Table 1). These occurrences can be divided in seven thematic categories; Category 1 , for instance, consists of those hits referring to TB-related diseases or deaths without a governmental diagnostic frame. The primary source analysis presented in Table $\mathbf{1}$ is indicative of the Canadian bureaucracy between 1900 and 1915 .

It is important to determine what kind of diagnostic frames prevailed, how they are used as justification mechanisms, and whether they com- 
plied with existing academic research and medical knowledge of the period between 1900 to 1915 .

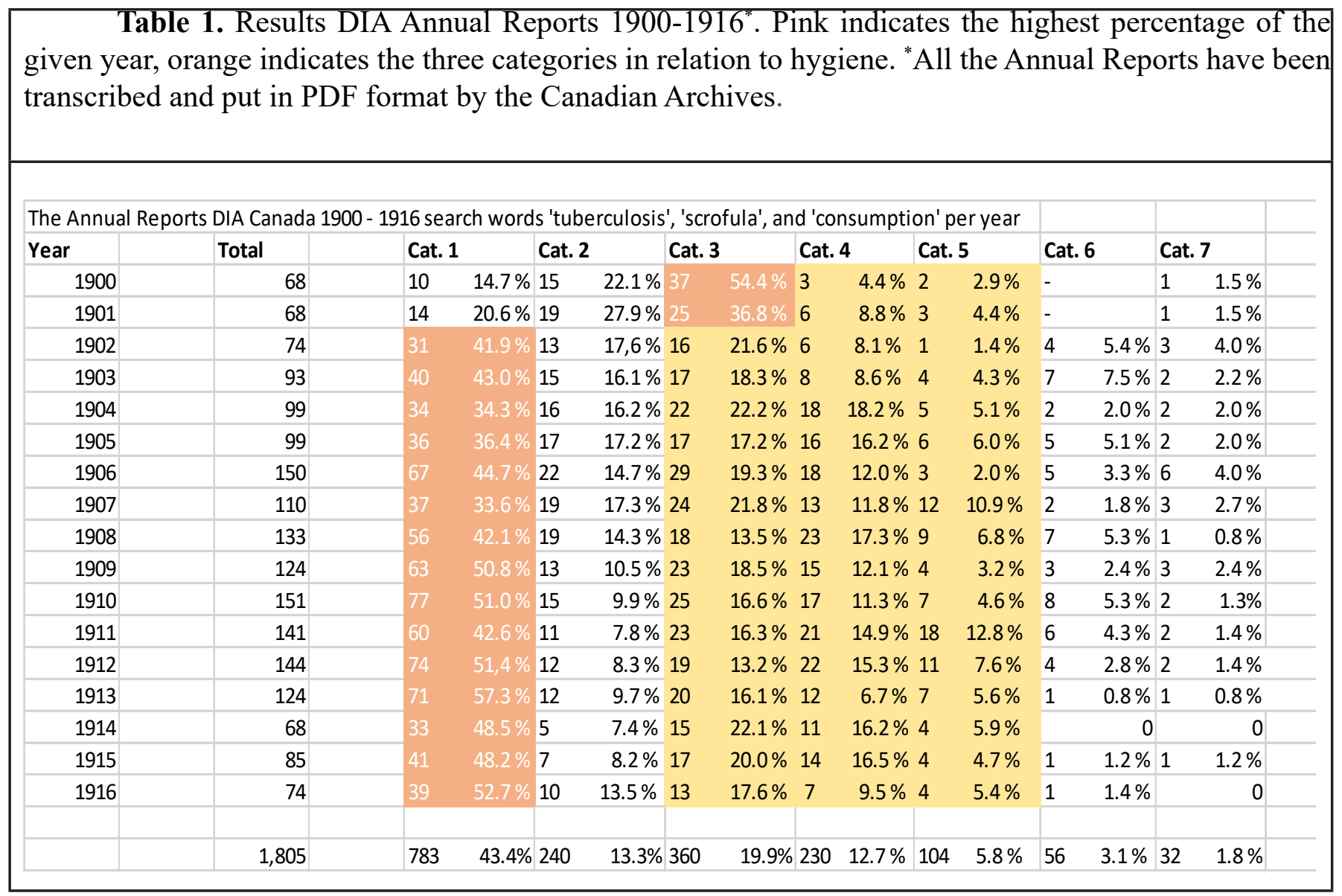

For the presentation of the frames, the following diagnostic categories are clustered:

- Category 1, word occurrences;

- Category 2, sickness due to race or hereditary proneness;

- Category 3, general standard of sanitation and ventilation;

- Category 4, in-house cleanliness and conditions;

- Category 5, personal morality seen in response to weather and eaten food;

- Category 6, level or lack of assimilation or civilization;

- Category 7, miscellaneous (e.g. caused by other diseases, God).

Yet it must be noted that diagnostic framing itself is coloured by the primary frame of how the DIA and its officials saw and categorized the world. The Canadian governance structure and Euro-Canadian worldviews were determined by scientific racism and the Indigenous peoples were considered savages. This state, however, was and is a social construct, wrongfully perceived as physical or biological science (Goffman 1975).
Nevertheless, many people believed in the scientific truth of racism between 1900 and 1915, including Euro-Canadians and the DIA (Kelm 1998).

Nevertheless, with the knowledge of TBrelated diseases as environmentally enhanced, as well as the neglected treaty responsibilities by the Canadian government, this case study goes beyond issues of race alone. The Annual Reports linked race to class and reveal that officials were 
aware of how political, economic, and socially determined circumstances such as malnourishment, overcrowding, and disease caused socio-economic and health disparities. Moreover, medical development and TB treatment in tented camps indicate a level of accountability. The argument of scientific racism, as a primary frame, might be used as an excuse against governmental guilt or blame and put forward as unintentional neglect between 1900 and 1915. However, in connection to continued socioeconomic and health gaps in twenty-first century Canada, this does not hold and questions if scientific racism became an institutionalized mechanism of structural genocide up until the twenty-first century.

\subsection{Government Fortuitousness}

In Table 1, the largest numbers are found in Category 1 and Categories 3 to 5 combined. This means government policy, or DIA functioning, was not blamed for the health and socio-economic deprivation of First Nations peoples on reserves or close to reserves in the Canadian Prairie West. In fact, it shows the blame was placed on the Indigenous peoples themselves, arguing their hereditary proneness to TB-related diseases; it was suggested that TB was a natural disease connected to a lack of assimilation and civilization.

In the Annual Reports of the years 1900 to 1916, ending in March 1916, "consumption" and "scrofula" as variations of TB were often connected to a lack of sanitation or seen as inherent "Indian" diseases. Some variations of TB, however, were also diagnosed as "white" diseases. Nevertheless, the DIA's categorizations of "Health" or "Health Conditions" grouped together with "Sanitation" or "Sanitary Conditions" does indicate TB infection was perceived as related to a lack of sanitation.

\section{1 \& 2)}

\subsection{TB as a Natural Disease (Categories}

The high percentages in Category 1 indicate TB-related diseases were only mentioned, without actual diagnostic framing as to why the disease occurred. DIA officials often indifferently specified the number of people that died on reserves each year. For instance, in 1905, TB, scrofula, and consumption were only mentioned to specify the death of a child or an elderly person, or by a death rate (DIA
Annual Report 1905). All reports featured general descriptions of TB, consumption, and scrofula being described as either "most pervasive," "most prevalent," or the "scourge of the Indian"; health was continuously linked to the 'Indian problem.'

TB-related diseases were seen as something inherent or biologically determined. Though category 2 on race does not reveal this perception, the first category indicates the "normal" proneness to disease the DIA ascribed to Indigenous peoples: "tuberculosis and scrofula continue to make inroads upon the race, but where tent hospitals have been introduced, and nursing as well as medical and surgical treatment has been provided, there has been a gratifying check to those dread scourges of the aborigines" (DIA Annual Report 1907, p. 302). The primordial "scourge" among Indigenous peoples is explained through scientific racism and could only be contained or limited through sanitary precautions and isolation.

TB-related diseases and the scourge of the "Indian" were furthermore explained through scientific racism and the stage of development, as the report claims "the high death-rate is attributed chiefly to the presence of tuberculosis and kindred scrofula, aggravated by the conditions attending the earlier stages of transition from the aboriginal to the civilized environment" (DIA Annual Report 1905 , p. 31, 429). This causality of development perceived as a necessary stage of evolution served as a justification mechanism for the lack of aid the Indigenous population was provided by white governance structures. Nevertheless, the DIA, when it incited and forced a state of transition onto people on reserves, indirectly hinted that the forced government policy of assimilation aggravated TB and kindred scrofula diseases.

The DIA categories in which TB, scrofula, or consumption were mentioned often combined remarks on the overall health of in-reserve populations and the lack of epidemic diseases with the "usual" TB-related diseases. TB, scrofula, and consumption were denied as being epidemic diseases but were met with the same sanitary precautions. In this way, TB-related diseases were seen as common, not epidemic, for Indigenous peoples due to their 
immoral ways of living. This argument served the DIA: it was frequently put forward that TB appeared naturally on all reserves irrespective of DIA policy.

The normalcy of disease was connected to ideas about the Indigenous peoples. According to a Treaty 8 Indian agent, "consumption and scrofula are the two inherent tendencies in the Indian constitution that make up the major portion of his ailments, either direct, or indirect, and when coupled with unnecessary exposure [...], the combination is one not tending to the physical well-being of the aborigines" (DIA Annual Report 1901, p. xxi). According to DIA officials, "Indians" were not "fully adapted $[\ldots]$ to their new environment, and that the process of selection under the law of 'survival of the fittest' [seemed] to be still in operation" (DIAAnnual Report 1903, p. xix). Full assimilation into a new environment had to be achieved gradually to form "constitutional resisting power to infection" (DIA Annual Report 1903, p. 32). However, this gradual improvement had to be done in a self-sufficient way, which included Indigenous peoples living in tents if infected and almost no help from the DIA.

\subsection{Lessons in Hygiene (Categories 3 \&}

4)

The third category, 'lack of sanitation', and the fourth category, 'living conditions', were often connected to ideas of Indigeneity (DIA Annual Report 1900). For the DIA, this Indigeneity, or perceived weak constitution of "Indians", together with a lack of sanitation and uncivilized ways, explained the high illness rates. In the Annual Report of 1901, the idea that malnutrition and poor housing added to the weak constitution of "Indians" made TB 'the great enemy of the Indian’ (DIA Annual Report 1901, p. i-xxi). In contrast, immoral living conditions were often created by the DIA, forcing Indigenous peoples into western housing formulas that were only partially successful. This resulted in poorly constructed houses that lacked garbage disposal or ventilation (DIA Annual Report 1901). Therefore, DIA policies were responsible for creating these living conditions and a lack of sanitation in the first place.

Meanwhile, living in tents, previously considered "savage" living conditions, were increas- ingly condoned as it proved to decrease the number of consumption, scrofula, or TB patients and became a sanitary precaution. According to the Indian agent of Enoch's band, "it is a well-known fact that when they [the "Indians"] are living practically in the open air, during spring, summer and autumn, their health is very much better [.However,] their mode of living, their feast and waste one day, compulsory fast the next, wet feet and often wet clothes, which are slept in, and their immoral lives [are undoubtedly the cause of] scrofula and consumption, the bane of the Indian" (DIA Annual Report 1901, p. 263). Thus, even though living in tents was acknowledged as beneficial to the general health, the DIA concluded that the immoral ways of the Indigenous peoples caused TB.

This paradox puzzled some DIA officials. In the Annual Report of 1902, some Indian agents realized that, despite sanitary measures and precautions, Indigenous peoples still suffered from TB (DIA Annual Report 1902). The Indian agents in question did not know what to think of the prevalence of the disease even in communities that had assimilated to a white standard. In the report of 1904, one Indian agent points out how, despite sanitary regulations and favourable living conditions compared to "their white neighbours," Indigenous peoples still suffered from consumption (DIA Annual Report 1904, p. xix). Regardless of this paradox, DIA policy was never questioned.

Mention of TB-related deaths in the context of residential schools was often immediately followed by praise for the schools' excellent sanitation and ventilation circumstances. The residential school staff was not held responsible as schools were written off consistently as "excellent" and "perfectly clean". Blame was placed, instead, on the general constitution of Indigenous peoples and their children: "the once robust and hardy constitutions of the Indians are becoming more and more degenerated, year after year, and in consequence more and more susceptible to contract this dreadful disease" (DIA Annual Report 1903, p. 171). In contrast, TRC reports and residential school memoirs point out the degeneration that occurred in the schools (Johnston 1988; Fontaine 2010; Robertson 
2011; Sellars 2012; TRC 2016; Merasty 2015). Moreover, the Annual Report of 1912 revealed how school administrations sent severely infected students home to prevent an increased death toll in schools, causing infection among family members.

The perceived primordial normalcy whereby Indigenous peoples were labeled as being prone to TB-related diseases is also connected to their biological lack of immunity to other diseases. For the years 1900 to 1915 , the seventh category in Table 1, "miscellaneous", often referred to TBrelated diseases caused by other diseases such as grippe or measles. For instance, in 1903, two miscellaneous cases referred to one acute TB-related death caused by typhoid fever and one caused by influenza (DIA Annual Report 1903). In 1906, a general higher rate of infectious diseases such as the whooping-cough, scarlet fever, influenza, and measles were seen as an explanation for increased TB infections among Indigenous peoples (DIA Annual Report 1906). The perception seemed to be that people on reserves simply got sick very often.

This diagnostic frame of inherent proneness to disease was furthermore connected to behaviour. In prairie conditions, white people would be cured from TB while Indigenous bands only got sicker; consequently, they would require rigid structure and assimilatory regiments (DIA Annual Report 1908). The isolation and segregation in separate hospitals, tents, or wards was the alternative to the retreat sanatoriums erected for white people (Lux 2001). It would have seemed that the objective of sanitary policies was aimed at destroying ways of living and achieve some level of civilization in the genocidal manner concluded by the TRC in 2015 (TRC 2015). The general idea regarding the increased death rate of Indigenous First Nations peoples by TB-related diseases served the "general progress in the direction of civilization [by] gradually removing and imparting power to resist the conditions peculiar to the Indians" (DIA Annual Report 1907, p. 35). Hence, white behaviour and civilized ways were perceived to eventually and naturally reduce the incidence of TB-related diseases among Indigenous peoples. DIA officials believed progress would put a halt to TB among Indigenous peoples and they had the idea that civilization and westward expansion would eventually save the "Indian": "extending settlement is gradually bringing more and more of the hitherto outlying bands within reach of scientific aid, and marked results have been obtained from treatment in tent hospitals experimentally introduced into certain localities" (DIA Annual Report 1907, p. 35). However, this line of reasoning was in direct opposition to the argument that those suffering from TB-related diseases were those in close contact with western medicine (Lux 2001).

Precautionary policies delineated in the reports praised medical treatment and segregation policies (DIA Annual Report 1907). Throughout the Annual Reports, the precautionary descriptions become more detailed, not only referring to sanitation and ventilation, but more explicitly referring to outhouses, drainage systems, heating mechanisms, water supplies, food, clothing, and fire protection. Increased emphasis was placed on the isolation and segregation of infected people from their houses, families, and reserves. Nevertheless, it is difficult to determine if the labelling of the DIA as "satisfactory functioning", "appropriate", and "considerable care" precautions were comparable to the standards provided to white middle and upper-class Euro-Canadian peoples and their children. The economic sections in the Annual Reports after 1910 suggested otherwise, as more money was spent on stationary than on precautions or health care for Indigenous peoples (DIA Annual Report 1910; 1912; 1913; 1914).

\section{Opposing Medical Views}

The general sentiment put forward in the Annual Reports is the idea that TB was the bigger term which encompassed consumption and scrofula (DIA Annual Report 1903). Treatments and operations on patients were mentioned more frequently after 1902, which might indicate that prior cases were not seen by a doctor. This increase in attention occurred simultaneously with insights on TB, scrofula, and consumption as dis- 
eases spread by germs. The urgency of the possible spread of the disease might have warranted increased medical treatment to prevent the possible infection of white settlers in the area (DIA Annual Report 1903). Nevertheless, general understanding remained that $\mathrm{TB}$, scrofula, and consumption were diseases similar in spreading and contagion to small-pox, measles, and whooping-cough and were treated with the same sanitary precautions and quarantine politics (DIA Annual Report 1904).

In 1911, a new theory on the housefly as spreader of TB related diseases emerged: "house flies are now recognized as most serious carriers of the germs of certain diseases" (DIA Annual Report 1911, p. 627). Even though this indicated that the spreading of the disease was not necessarily linked to behaviour, the housefly only served as another indication of Indigenous unhygienic behaviour; after all, civilized households were believed to not have houseflies. This theory on the housefly also meant civilization was connected to class. For example, according to the DIA Annual Report of 1905, poor white communities were also living in unhygienic circumstances and suffered from TB-related diseases more often.

TB-related diseases, thus, also prevailed among poor white communities in big cities: "when so comparatively little has been achieved in combating the ravages of tuberculosis among the white race, it cannot be wondered at that the Indians continue to suffer greatly from this dread disease" (DIA Annual Report 1905, p. 320). Therefore, the assumption was made that if working and lower-class white people suffered from $\mathrm{TB}$, Indigenous peoples, whom lagged further behind in the stages of development, would also have to suffer the same or more. In this way, Indigenous peoples were assumed to suffer from TB-related diseases based on their race and class.

Physician P. H. Bryce made his first appearance as Chief Medical Officer of the DIA in the 1905 report, pointing out that DIA policy was based on notions of race and class. TB and scrofula were diseases and not the result of "contact of so-called civilized races with the native untutored races of the several continents" (DIA Annual Re- port 1905 , p. 468). Bryce suggested an increase in government spending and similar policies as those that had been implemented for white communities. Bryce advised the DIA "to isolate the patients, particularly those in the advanced stages [in] some cottages or a small consumptive hospital for winter accommodation, and then have tents, double-walled tents," in line with the high standard of health regulations available in Canada and England (DIA Annual Report 1905, p. 473).

Another point of view featured in the DIA reports was that of physician A. G. Meindl, who suggested that the blame should be placed on Indigenous peoples and their poor assimilation to reserve life. According to Meindl, "the tendency which long ago was shown for these children of nature to imitate the vices rather than the virtues of, the white man, has proved the wisdom of placing the reserves distant from settlement, even from the standpoint of health" (DIA Annual Report 1906, p. 431). In contrast to the DIA's ideas, Meindl saw development and westward expansion as degrading to Indigenous health and, most importantly, as a threat to white communities because "evidence is at hand that those bands which have remained roving bands of hunters and trappers have been freer from disease than have been those who have adopted the settled manner of life on reservations" (DIA Annual Report 1906, p. 431). But again, the DIA policy was not altered or questioned. In comparing the DIA entries, it is clear how Bryce disagreed with Meindl. Bryce, and instead saw the causes of TB-related disease among Indigenous peoples more regarding DIA policy (DIAAnnual Report 1907, p. 439). Hygienic prescriptions were not followed by those in charge on the reserves and in the residential schools. For instance, "in almost all [residential schools] there were present cases of tuberculosis of the scrofulous form, and in very few were there evidences of an adequate appreciation of the dangers threatening the other pupils [...]. Everywhere was too apparent the fear that their exclusion might lessen the per capita grant" (DIA Annual Report 1905, p. 443). Lack of money caused deteriorated living conditions for the pupils as the minimal allowance from the DIA did not al- 
low for investments other than bare necessities.

In almost all instances, medical advice was ignored. DIA officials in 1907 claimed Indigenous peoples "blood appears to be so impure and so contaminated with scrofula," that not much could be done (DIAAnnual Report 1907, p. 399). Controlled and altered dietary regulations were the only policies implemented in most schools, but altered diets would neither be realized nor increased the dairy products, which later proved to be contaminated by TB as well (TRC 2015). Moreover, medical knowledge on the digestive origin of TB infection was already mentioned by 1908: "medical science now recognizes that it is digestive troubles due to improper food in infancy that not only cause many deaths from diarrheal diseases, but which also prepare through these inflamed tracts the tissues for the reception of the bacillus of tubercle, whether as actually tuberculous meat or milk, or from infected house faith and dust actually getting into the food through hands, dishes [...]" (DIA Annual Report 1908 , p. 478). This medical knowledge on TB infection in relation to government rations, cattle, and environmental living conditions was already available in 1908, circulated in DIA reports, and ignored.

Even ideas on the hereditary proneness to TB were partially declared unfounded in 1908. According to physician Dr. J. R. Walker, the causal factor of TB infection among Indigenous peoples was explained as external rather than primordial: "tuberculosis among these Indians does not differ in any respect from tuberculosis amongst white people. [...] There is no inherent peculiarity which renders him more liable to infection from tuberculosis than is a white man under like circumstances [...] a much larger proportion of these Indians than of the white people are infected with tuberculosis. This must be the result of external conditions that do not especially pertain to the Indian" (DIA Annual Report 1908, p. 479).

Additionally, the DIA reports as early as 1908 featured entries in which TB was seen as a pre-contact disease, meaning tuberculosis existed among the Indigenous population before contact with Euro-Canadians, "but at that time the disease was, rare among them and remained so until they changed their nomadic to a settled life in houses" (DIA Annual Report 1908, p. 479). TB and related diseases were perceived by some as not biologically new, but rather increased through European contact: "when they began to live in houses, tuberculosis began to increase among them, so that the conditions that caused this increase must have been different from those surrounding them when they lived in tepees" (DIA Annual Report 1908, p. 479). However, DIA and government policies still were not held accountable or scrutinized.

As a matter of fact, the 1908 report also denounced sanitary explanations as instigating TB infection, which stated that "they were filthy, both when they lived in tepees and when they lived in houses. [...] There is no evidence that this filth ever caused tuberculosis except when it was mingled with the specific germs of the disease" (DIA Annual Report 1908, p. 479). Despite the arguments on germ theory that developed, TB was still connected to the idea of the frail constitution of Indigenous peoples. These frail constitutions were further compromised by "the sudden change from their former way of living" (DIA Annual Report 1908, p. 485). Despite all these medical arguments, physicians and DIA officials alike still blamed Indigenous peoples and not Euro-Canadian expansion or DIA policy. The idea of a logical progression of history prevailed, and high morbidity and mortality rates among those Indigenous peoples shifting towards civilization were therefore justified.

Moreover, in an indirect response to Doctors Walker, Bryce, and Meindl, DIA Indian Commissioner David Laird suggested that the development of unsanitary dwellings to white standards of living, as well as general assimilation, had proven successful when conducted properly (DIA Annual Report 1908). According to Laird, "the ravages of tuberculosis are a consequence of the change from the former roving life of the Indians under canvas to their now more sedentary conditions of existence and to their life in unsanitary and ill ventilated dwellings" (DIA Annual Report 1908, p. 332). Ironically, the imposed DIA policy and changes to sedentary conditions are not linked or questioned. Increased TB remained part of the pro- 
cess of civilization as "the progress of civilization shows that it often creates difficulties for those it is designed to benefit before removing the evils which it is intended to cure" (DIA Annual Report 1908, p. 333). Collectively, DIA reports featured medical knowledge from Doctors Meindl, Bryce, and Walker, but were ignored by DIA officials.

Many anti-tuberculosis campaigns after 1910 were based on race, class, and the public intimidation. Campaigns and research compared TB rates from white and "negro" populations were still seen in medical research in Canada and the United States through to 1937 (Long, 1937). "The Indian race [was] suffering," and in 1910 active anti-tuberculosis campaigns were started outside of DIA policy "because of the danger to the white man" (DIA Annual Report 1910, p. 423). Indigenous peoples were continuously perceived as the inferior class and race within the public and various medical opinions. Combined ideas on class and race made TB among reserve populations something almost incurable. Public opinion and DIA policy continuously displayed relative indifference to the death rate among Indigenous peoples and their children.

\section{Institutionalized Marginalization and Structural Genocide}

The TRC reports of 2015 and 2016 gave considerable attention to the high morbidity and mortality rates in residential schools due to diseases such as TB. The Canadian government and involved churches have issued formal apologies for their involvement in the residential school system. Moreover, the TRC concluded that the residential school system was part of "a conscious policy of cultural genocide" (TRC Final Report, 2016). Nevertheless, the term "cultural genocide" has no judicial resonance, and the general socioeconomic gap that also causes higher TB rates remains. The TRC defines cultural genocide as "the destruction of those structures and practices that allow the group to continue as a group [which] prevent the transmission of cultural values and identity from one generation to the next" (TRC Final
Report, 2016). Despite the formal apologies and TRC reports, the term cultural genocide has not generated social reform in terms of legal impact.

The lack of judicial resonance relates to international law and the connection of the Canadian government to international law. According to Canadian law expert William Schabas, cultural genocide does not exist under international law (Schabas 2000). The Genocide Convention, established after the Second World War, never included "cultural genocide". The initiator of the term genocide, Raphael Lemkin, did distinguish different types of genocide, including cultural genocide, but these were never incorporated in the Convention (Davidson 2012). The distinction of cultural genocide was deemed too vague and broad by representatives at the time (Abtahi and Web 2008). Therefore, legally, the definition of genocide is limited to the direct "intent to destroy, in whole or in part, a national, ethical, racial or religious group," rather than including indirect policies with the same destructive result (UN 1948, p. 280).

Moreover, as a historical term, genocide remains complex, with strong normative links to the Second World War and the Holocaust. Genocide is often used to refer to specific anti-Semitism politics of destruction during the Second World War and may result in a heavily charged idea that nothing was as bad as the Holocaust. Another complexity of the term genocide resides in its origin. During the 1940s, genocide was stipulated as non-retroactive by the Genocide Convention and only applicable to crimes against humanity after 1948 (Schabas 2000). Genocide is also viewed as having a beginning and an end, as well as being something temporal rather than a continuous structural process such as within colonialism.

Canada only recently acknowledged the Convention on Genocide (UN Treaty Collection [accessed 2016]). The UN Declaration of Indigenous Rights, which also deals with acts of genocide, was accepted by the Trudeau government (Carnegie Council [accessed 2016]). Canada previously voted to keep cultural genocide out of two major United Nations documents, and even recent recognition of cultural genocide excludes some of 
the legal implications of genocide. Moreover, the instalment of the TRC was funded by a class-action lawsuit filed by Indigenous peoples against the $\mathrm{Ca}$ nadian government, but excluding financial restitutions following the cultural genocide conclusions.

As Australian anthropologist Patrick Wolfe (2006, p. 403), wrote:

It [structural genocide] avoids the question of degree - and, therefore, of hierarchy among victims - that are entailed in qualified genocides, while retaining settler colonialism's structural induration [...]. Given a historical perspective on structural genocide, we can recognize its being in abeyance [...] rather than being a thing of the past.

This quote, seemingly unrelated to the persistence of TB related diseases, was mentioned by Health Canada in the introduction of this research. Wolfe regards the term "cultural genocide" as equally problematic as Canadian law expert William Schabas and the Canadian government but not because of its legal limitations. Rather, Wolfe suggest the term "structural genocide" to fully capture the institutional marginalization inferred from the past DIA official documents, the present census reports and the consequences on, for example, TB rates among Indigenous peoples.

Wolfe describes structural genocide as the continued settler-colonial eliminatory policies toward Indigenous peoples, of which an example is the morbidity and mortality rates caused by TBrelated diseases that continues to this day (Wolfe 2006, p. 390). As such, apologies from the Canadian government and church bodies as settler-colonial structures for past abuses and cultural genocide are partial and do not accurately describe the structural character of the relationship between Indigenous First Nations peoples and Canadian hegemony, past or present. Covert and institutionalized marginalization is not only cultural, but has political, social, economic, religious, and other structural implications for Indigenous peoples (CIR [accessed 2016]).

According to Wolfe, cultural genocide, besides being legally void, indicates a form of geno- cide to describe an event like the Holocaust, but not really (Wolfe 2006). Rather, structural genocide is a term that more accurately describes the continued domination and privation of the Indigenous peoples by the Canadian state. Structural genocide can also be explained through the "logic of elimination". This "logic of elimination" explains the settler-colonial constructs the necessity to dispose of the Indigenous peoples for the purpose of acquiring territory for the incoming Europeans. Wolfe compares the difference between slavery and Indigenous people suggesting that while the reproduction of enslave people was seen as a benefit to the owner, the growth of Indigenous populations was seen as an obstruction to the settler's access to land: "in this way [through] the restrictive racial classification of Indians straightforwardly furthered the logic of elimination" (Wolfe 2006, p. 388). The logic and the racial classifications that decreased Indigenous populations on Canadian soil are no partial or cultural form of genocide as concluded by the TRC - in fact, they are structural.

Australian researcher Keith Windschuttle uses this logic of elimination to deny both Western responsibility for Indigenous displacement or genocide (Windschuttle 2001). According to Windschuttle (2001, p. 41), while reflecting on Australian history, but equally applicable to Canada, there was no covert government genocide: "it was just the normal progression of colonial development". Even if there was warfare among the British troops and the Aborigines, this was a normal feat of history. In opposition to Windschuttle (2001)'s explanation of the logic of elimination as a temporal phase in history, Wolfe focuses on the continuous aftermath of colonial war and structural institutionalized racism of colonial governance over its Indigenous subjects.

The continuous aftermath of structural genocide connected to contemporary health disparity shows how imbalances experienced by Indigenous peoples in Canada today are a result of historical displacement on reserves and the residential school system, which caused and continue to cause socio-economic poverty. Moreover, this structural process is monitored and maintained by the Canadian government. The restrictive racial classifica- 
tions after the 1870s have important immaterial and material consequences for Indigenous peoples in Canada (Andersen 2013; Andersen 2014). Not only did these ideas of race fuel harsh policies of segregation, starvation, and assimilation in the nineteenth and twentieth centuries, which caused socio-economic disparities and health issues, these ideas and their consequential disparities still hold effect in the twenty-first century (Milloy 1999).

In turn, structural marginalization validates the previously mentioned concept of the "White Man's Burden" in Canadian government to aid Indigenous peoples without structural social reform taking place. According to Milloy (1999), DIA intervention destroyed traditional economies, thus creating impetus for intensive welfare intervention without achieving anything. Even though Milloy (1999) recounts date from 1879, I found it is applicable to 2016 as well. According to Andersen, five generations of Indigenous peoples were in and off reserves as result of the government welfare intervention and the "White Man's Burden", but there was no quantifiable investment in the communities. This produced longterm deteriorating conditions. Subsequently, these conditions were evidence of Indigenous peoples' developmental lag behind other Canadians (Andersen 2013, p. 634). This situation was already apparent in the DIA reports between 1900 and 1915.

Andersen concludes how Canadian society is still determined by the organization of peoples according to specific historically embedded political imaginaries that justify government intervention and continuous subjugation of Indigenous peoples (Andersen 2013, p. 634). Today, these political imaginaries of Indigenous subordination solidified in law and government cause a constant tension between Indigenous peoples seeking sovereignty and self-determination and non-Indigenous groups in Canada. Historically, constituted imaginaries are still based on embedded imaginaries of racial difference and class hierarchy. Moreover, politics of reconciliation and recognition pursued by the Canadian government in the twenty-first century are new justification mechanisms and reinvented tactics of scientific racism and interven- tion, through which the Canadian government manages its control and sovereignty over Indigenous peoples (Turner 1998, 2000; Alfred 2005; Coulthard 2014; Simpson 2014; Andersen 2013).

According to Smith, this reinvention of government control is a logical state mechanism of liberal capitalist nations (Smith 2009). The government control theory of Michel Foucault calls it the "panopticon" principle, meaning subjects of the state are policed and under strict, prison-like surveillance. Moreover, liberal capitalism's goals are to control the flow of money and favour the liberal majority (Foucault 1975). As a result, opponents - and in this case Indigenous peoples - are subjected to the rule and domination of the settler-colonial state policed by the Canadian government. A loss of government control would mean the loss of territory, which would result in the loss of means of income retrieved from that territory (Foucault 1975; Stoler 1995).

As such, according to Smith (2009), this political imaginary directly affects Indigenous peoples. Political imaginaries and Othering by the Canadian surveillance state continuously influence ideas about Indigenous peoples in more than just cultural ways. The DIA as a governmental structure functioned as part of this surveillance panopticon, a web informed by liberalism and market economics that created "structures that continue to oversee the life-threatening material conditions faced by many Indigenous peoples in Canada" (Smith 2009, p. cover).

The historical research on post-colonial Canada functions mostly as a critique of notions of the great white narrative of history (Smith 2009). Their main arguments incorporate personal correspondence of DIA officials and Indigenous counter-narratives to form a more complex picture of the construction of Canada. Publications during the early twenty-first century have pointed to the lack of historical attention given to Canada's history of violence against Indigenous peoples (Rimmer 2015; Moreton-Robinson 2016). Their conclusions question the white normativity of Canadian history; however, they still often avoid difficult questions of genocide. 


\section{Conclusions}

TB-related diseases were continuously framed as the fault of Indigenous communities in all six categories discerned in Table $\mathbf{1}$ following the DIA's Annual Reports. Perspectives on lifestyle, inadequate hygiene, hereditary proneness to the disease, and stages of civilization all singled out the "Indian" as the problem. Yet the general tone of voice regarding TB moved from relative indifference to a more careful consideration of the disease and its possible spread to white people. The DIA as the complete and sole administrative power, categorized Indigenous peoples and disease according to its perceptions on race, class, and civilization between 1900 and 1915. Not only were these perceptions on race and class used uncritically, but even medical knowledge and some awareness about the unfoundedness of these perceptions were available and ignored.

The DIA as a public institution was almost completely void of any self-critical reflection and denounced entries by physicians who claimed otherwise. As such, the diagnostic frames discerned directly correspond to the carelessness of the Canadian government and the DIA toward their wards. Further underlining the lack of introspection within the DIA is suggested by the thematic category with the most hits which refers to the indifference towards the morbidity and mortality rates caused by TB-related diseases. In the words of Laird, the DIA believed the progression of history and the progress of civilization necessitated "difficulties" for Indigenous peoples before "removing the evils which it is intended to cure" (DIAAnnual Report 1908, p. 333).

Making the link to today using the TRC reports and recent policies of recognition and reconciliation, this review shows how the disparities in living conditions, and other social determinants of the health of First Nations people and mainstream Canadians are still present (Daschuk 2013, p. 186). The analysis made by Wolfe (2006) on structural genocide rather than cultural genocide on Indigenous peoples in Canada is furthermore an important distinction to critically analyse the intrinsic in- tutional marginalization of First Nations peoples.

The conclusion of cultural genocide established by the TRC can be criticized as partial and incomplete. The DIA report research combined with academic discussion suggests more reason to accept Wolfe's analysis of the term "structural genocide" as a description of Canadian reality. Not only does the term accurately describe the continuous character through which Indigenous peoples are governed, it also describes the Canadian government and system's ability to change its public political perspective while maintaining institutionalized marginalization established in the $1870 \mathrm{~s}$ through the Indian Act and its later amendments.

This institutionalized racism is exemplified in the recent politics of reconciliation and renewed political attention for Indigenous peoples in need of help without granting any social betterment or reform through self-determination or sovereignty. In the eyes of critical Indigenous scholars, politics of recognition and reconciliation employed by governing parties are forms of neo-colonization and domination that deny Indigenous self-determination or sovereignty, as has been done since the signing of the treaties (Turner 1998, 2000; Alfred 2005; Coulthard 2014; Simpson 2014; Andersen 2013). In reaction, Indigenous politics of refusal and, ultimately, ideas of coexistence increasingly emerge.

The coexistence remains a struggle for territory and the lack of spatial justice. Through treaties and segregationist policies both before and after 1900, Indigenous peoples have come to inhabit those territorial spaces that lack socioeconomic access, political opportunities, or health services normally available to other people. The axis of race, class, and politically institutionalized marginalization reinforces ideas that Indigenous peoples are unable to take care of themselves.

This review, with its analysis of the DIA Annual Reports in relation to the TRC, vouches for the term structural genocide rather than cultural genocide. This problematizes our understanding of post-colonialism and its relation to race, genocide, and Indigenous sovereignty and self-determination in Canada today. Notions of western white governance structures, past and present, and white nor- 
mativity as an institutionalized marginalization mechanism are hard to be proven, fundamentally altered, or deconstructed. However, the diagnostic frame analysis provided here however reveals how public political mechanisms and imaginaries lack an inward inspection. Moreover, environmentally enhanced conditions that explain the socio-economic and health gap between Indigenous peoples and non-Indigenous groups in Canada can only be accurately assessed through critical self-examination of government institutions discussed in this review.

Canada believes in the "mythology of racelessness" (Smith 2009, p. 23). This review deconstructs some of this mythology and unravel alleged racelessness of Canadian welfare and health. Whereas Windschuttle (2001) rejects any western responsibility for Indigenous displacement and genocide, other scholars such as Foucault, Andersen, Smith, Alfred, Simpson, Coulthard, and Daschuk signify this progression of history as a form of colonialism with an internal marginalization of Indigenous peoples. The continuous aftermath of colonialism and structural institutionalized racism of a colonial governance over its Indigenous peoples created a cycle in history that made Indigenous marginalization not just a thing of history but an enduring structural reality.

Future research would benefit from a comparative analysis in other postcolonial contexts. The enduring gap in health and socio-economic circumstances is indicative of the structural character and all-encompassing form of subjugation of so-called postcolonial societies. The crosscultural process and strategy behind the Canadian Indian policy was informed by similar processes in the United States, New Zealand, and Australia. In general, nineteenth and twentieth-century government framing processes have been highly instructive for both the collective or individual identity formations of both Euro-Canadian people and Indigenous peoples, and warrant deconstruction and analysis (Snow and Benford 2000).

\section{Disclosure}

This paper was derived from the author's Master Thesis. The full thesis is accessible at: https:// dspace.library.uu.nl/handle/1874/338952

\begin{abstract}
Acknowledgement
The author is thankful of the three anonymous reviewers whose valuable comments help in refined and improved the manuscript.
\end{abstract}

\section{Cite As}

Mudde L. 2018. Structural Genocide and Institutionalized Racism in Canada: The Department of Indian Affairs and Framing of Indigenous Peoples. Alberta Academic Review Journal, Vol 1 (1) 15 - 37, DOI: 10.29173/aar10

\section{References}

Abogiginal Affair and Northern Development Canada. (2018). Welcome to the First Nation Profiles Interactive Map. Goverment of Canada. Accessed March 2018. http://cippn-fnpim. aadncaandc.gc.ca/index-eng.html

Abtahi H, Web, P. (2008). The Genocide Convention: The Travaux Préparatoires. Leiden (NL): Martinus Nijhoff Publishers.

Alfred T. 2005. Wasáse: Indigenous Pathways of Action and Freedom. Toronto (ON): University of Toronto Press.

Andersen C. 2014. "Métis": Race, Recognition and the Struggle for Indigenous Peoplehood. Vancouver (BC): UBC Press.

Andersen C. 2013. Indigenous Statistics: A Quantitative Indigenous Methodology. Walnut Creek (CA): Left Coast Press.

Battiste M, Henderson JSY. 2000. Protesting Indigenous Knowledge and Heritage: A Global Challenge. Saskatoon (SK): Purich Publishing.

Carter S. 1999. Aboriginal People and Colonizers of Western Canada 2nd ed. Toronto (ON): University of Toronto Press.

Carter S. 1990. Lost Harvests: Prairie Indian Reserve Farmers and Government Policy. Montreal (QC): McGill-Queen's Press.

Cook-Lynn E. 1997. Who Stole Native American Studies? Wicazo Sa Review 12(1): 9-28.

Cook-Lynn E. 1998. American Indian Studies: An Overview. Wicazo Sa Review 13(1): 14-24.

Coulthard GS. 2014. Red Skins, White Masks: Rejecting the Colonial Politics of Recognition. 
Minneapolis (MN): University of Minnesota Press.

Darden JT, Kamel SM. 2002. The Spatial and Socioeconomic Analysis of First Nation People in Toronto CMA. Canadian Journal of Native Studies 22(2): 239-67.

Daschuk JW. 2013. Clearing the Plains: Disease, Politics of Starvation, and the Loss of Aboriginal Life. Regina (SK): University of Regina Press.

Davidson L. 2012. Cultural Genocide. New Brunswick (NJ): Rutgers University Press.

DIA Annual Report. 1900. Dominion of Canada Annual Report of the Department of Indian Affairs for the Year Ended June 30, 1900. Ottawa, Library and Archives Canada [accessed Apr 2015 www.bac-lac.gc.ca/eng/discover/ aboriginal-heritage/first-nations/indian-affairsannual-reports].

DIA Annual Report. 1901. Dominion of Canada Annual Report of the Department of Indian Affairs for the Year Ended June 30, 1901. Archive. Ottawa, 1901. Library and Archives Canada [accessed Apr 2015 www.bac-lac.gc.ca/eng/ discover/aboriginal-heritage/first-nations/indian-affairs-annual-reports].

DIA Annual Report. 1902. Dominion of Canada Annual Report of the Department of Indian Affairs for the Year Ended June 30, 1902. Ottawa, Library and Archives Canada [accessed Apr 2015 www.bac-lac.gc.ca/eng/discover/ aboriginal-heritage/first-nations/indian-affairsannual-reports].

DIA Annual Report. 1903. Dominion of Canada Annual Report of the Department of Indian Affairs for the Year Ended June 30, 1903. Ottawa, Library and Archives Canada [accessed Apr 2015 www.bac-lac.gc.ca/eng/discover/ aboriginal-heritage/first-nations/indian-affairsannual-reports].

DIA Annual Report. 1904. Dominion of Canada Annual Report of the Department of Indian Affairs for the Year Ended June 30, 1904. Ottawa, Library and Archives Canada [accessed Apr 2015 www.bac-lac.gc.ca/eng/discover/ aboriginal-heritage/first-nations/indian-affairs- annual-reports].

DIA Annual Report. 1905. Dominion of Canada Annual Report of the Department of Indian Affairs for the Year Ended June 30, 1905. Ottawa, Library and Archives Canada [accessed Apr 2015 www.bac-lac.gc.ca/eng/discover/ aboriginal-heritage/first-nations/indian-affairsannual-reports].

DIA Annual Report. 1906. Dominion of Canada Annual Report of the Department of Indian Affairs for the Year Ended June 30, 1906. Ottawa, Library and Archives Canada [accessed Apr 2015 www.bac-lac.gc.ca/eng/discover/ aboriginal-heritage/first-nations/indian-affairsannual-reports].

DIA Annual Report. 1907. Dominion of Canada Annual Report of the Department of Indian Affairs for the Year Ended March 31, 1907. Ottawa, Library and Archives Canada [accessed Apr 2015 www.bac-lac.gc.ca/eng/discover/ aboriginal-heritage/first-nations/indian-affairsannual-reports].

DIA Annual Report. 1908. Dominion of Canada Annual Report of the Department of Indian Affairs for the Year Ended March 31, 1908. Ottawa, Library and Archives Canada [accessed Apr 2015 www.bac-lac.gc.ca/eng/discover/ aboriginal-heritage/first-nations/indian-affairsannual-reports].

DIA Annual Report. 1909. Dominion of Canada Annual Report of the Department of Indian Affairs for the Year Ended March 31, 1909. Ottawa, Library and Archives Canada [accessed Apr 2015 www.bac-lac.gc.ca/eng/discover/ aboriginal-heritage/first-nations/indian-affairsannual-reports].

DIA Annual Report. 1910. Dominion of Canada Annual Report of the Department of Indian Affairs for the Year Ended March 31, 1910. Ottawa, Library and Archives Canada [accessed Apr 2015 www.bac-lac.gc.ca/eng/discover/ aboriginal-heritage/first-nations/indian-affairsannual-reports].

DIA Annual Report. 1911. Dominion of Canada Annual Report of the Department of Indian Affairs for the Year Ended March 31, 1911. Ot- 
tawa, Library and Archives Canada [accessed Apr 2015 www.bac-lac.gc.ca/eng/discover/ aboriginal-heritage/first-nations/indian-affairsannual-reports].

DIA Annual Report. 1912. Dominion of Canada Annual Report of the Department of Indian Affairs for the Year Ended March 31, 1912. Ottawa, Library and Archives Canada [accessed Apr 2015 www.bac-lac.gc.ca/eng/discover/ aboriginal-heritage/first-nations/indian-affairsannual-reports].

DIA Annual Report. 1913. Dominion of Canada Annual Report of the Department of Indian Affairs for the Year Ended March 31, 1913. Ottawa, Library and Archives Canada [accessed Apr 2015 www.bac-lac.gc.ca/eng/discover/ aboriginal-heritage/first-nations/indian-affairsannual-reports].

DIA Annual Report. 1914. Dominion of Canada Annual Report of the Department of Indian Affairs for the Year Ended March 31, 1914. Ottawa, Library and Archives Canada [accessed Apr 2015 www.bac-lac.gc.ca/eng/discover/ aboriginal-heritage/first-nations/indian-affairsannual-reports].

www.bac-lac.gc.ca/eng/discover/aboriginal-heritage/first-nations/indian-affairs-annual-reports].

DIA Annual Report. 1915. Dominion of Canada Annual Report of the Department of Indian Affairs for the Year Ended March 31, 1915. Ottawa, Library and Archives Canada [accessed Apr 2015 www.bac-lac.gc.ca/eng/discover/ aboriginal-heritage/first-nations/indian-affairsannual-reports].

DIA Annual Report. 1916. Dominion of Canada Annual Report of the Department of Indian Affairs for the Year Ended March 31, 1916. Ottawa, Library and Archives Canada [accessed Apr 2015 www.bac-lac.gc.ca/eng/discover/ aboriginal-heritage/first-nations/indian-affairsannual-reports].

Carnegie Council. 2016. Carnegie Council for Ethics in International Affairs: The UN Human Rights Committee's Decisions 2005. [online]. Available: https:/www.carnegiecouncil.org/ search-results? $\mathrm{q}=$ indigenous + canada.

CBC News. 2016. 48\% of non-Aboriginal Canadians blame residential schools for current problems aboriginal people face [accessed Jun 2016 http://www.cbc.ca/news/indigenous/nationalsurvey-indigenous-attitudes-1.3620705]

CIR. 2016. Contemporary Indigenous Realities [online]. Accessed Jun 2016, available: https:// sokrat.ffos.hr/cir/.

Dyck N. 1997. Differing Visions: Administering Indian Residential Schooling in Prince Albert, 1867-1995. Fernwood Publishing.

Entman RM. 1993. Framing: Toward Clarification of a Fractured Paradigm. Journal of Communication 43(4): 51-59.

Fontaine P. 2010. Broken Circle: The Dark Legacy of Indian Residential Schools. Vancouver (BC): Heritage House Publishing.

Foucault M. 1975. Discipline and Punish: The Birth of the Prison. London (ON): Penguin.

Froehlich R, Rüdiger B. 2005. Framing Political Public Relations: Measuring Success of Political Communication Strategies in Germany. Elsevier.

Goffman E. 1975. Frame Analysis: An Essay on the Organization of Experience. Boston (MA): Northeastern University Press.

Harris IC. 1993. Whiteness as Property. Harvard Law Review 106(8): 1707-91.

Henderson J, Wakeham P. 2013. Reconciling Canada: Critical Perspectives on the Culture of Redress. Toronto (ON): University of Toronto Press.

Hildebrandt W, Carter S, First Rider D. 1996. The True Spirit and Original Intent of Treaty 7. 3rd ed. Montreal (QC): McGill-Queen's Press.

Johnston BH. 1988. Indian School Days. Toronto (ON): Key Porter Books.

Kelm, ME. 1998. Colonizing Bodies: Aboriginal Health and Healing in British Columbia, 1900 - 50. Vancouver (BC): UBC Press.

Leslie JF. 2002. The Indian Act: A Historical Perspective. Canadian Parliamentary Review.

Lakoff G. 2002. Moral Politics: How Liberals and Conservatives Think. Illinois (IL): University of Chicago Press. 
Long ER. 1937. A Brief Comparison of Tuberculosis in the White, Indian and Negro Races; Tuberculosis Control in Indians and Negroes: A Report to Surgeon General L. R. Thompson. University of Pennsylvania Press Report of the Henry Phipps Institute for the Study, Treatment, and Prevention of Tuberculosis Edition: 27.

Lux MK. 2001. Medicine That Walks: Disease, Medicine, and the Canadian Plains Native People, 1880-1940. Toronto (ON): University of Toronto Press.

Mako S. 2012. Cultural Genocide and Key International Instruments: Framing the Indigenous Experience. International Journal on Minority and Group Rights 19: 175-94.

Merasty JA. 2015. The Education of Augie Merasty: A Residential School Memoir. David Carpenter contributor. Saskatchewan (SK): University of Regina Press.

Milloy JS. 1999. A National Crime: The Canadian Government and the Residential School System, 1879 to 1986. Manitoba Studies in Native History. Winnipeg (MA): University of Manitoba Press.

Moreton-Robinson A. 2003. I Still Call Australia Home: Indigenous Belonging and Place in a White Postcolonizing Society. In: Ahmed S, Castada C, Fortier A, Sheller M, editors. Uprootings/Regroundings: Questions of Home and Migration. Sydney (NSW): Berg Publishers, 2003. p. 23-40.

Moreton-Robinson A. 2016. Critical Indigenous Studies: Engagements in First World Locations. Phoenix (AZ): University of Arizona Press.

Nakayama KT, Krizek RL. 1995. Reading in Rhetorical Criticism. 3rd ed. Fort Collins (CO): Colorado State University Press. Whiteness: A Strategic Rhetoric.

Price R. 1999. The Spirit of the Alberta Indian Treaties. Edmonton (AB): University of Alberta Press.

Public Health Agency of Canada. 2013. The Chief Public Health Officer's Report on the State of Public Health in Canada, Infectious Disease,
The Never-Ending Threat. [accessed through Public Health Agency of Canada, 2013 Oct 23]. www.publichealth.gc.ca

Reuters. 2009 Sep 26. Every G20 Nation Wants to Be Canada, Insists PM. Reuters. [accessed 2016 May 1]. www.reuters.com/article/columns-us-g20-canada-advantages

Rimmer M. 2015. editor. Indigenous Intellectual Property: A Handbook of Contemporary Research. 2nd ed. Research Handbooks in Intellectual Property Series. Sydney (NSW): Edward Elgar Publishing.

Robertson D. 2011. Sugar Falls: A Residential School Story. Illus. Scott Henderson. Winnipeg (MB): Highwater Press.

Russell B. 1984. White Man's Paper Burden: Aspects of Record-Keeping in the Department of Indian Affairs. Archivaria 19: 50-72.

Schabas WA. 2000. Genocide in International Law: The Crimes of Crimes. Oxford: Cambridge University Press.

Sellars, B. (2012). They Called Me Number One: Secrets and Survival at an Indian Residential School. Vancouver (BC): Talonbooks.

Simpson A. 2014. Mohawk Interruptus: Political Life Across the Boarders of Settler States. Durham (ON): Duke University Press. Chapter 1, Indigenous Interruptions: Mohawk Nationhood, Citizenship and the State; and, Chapter 5, Borders, Cigarettes, and Sovereignty.

Smith DK. 2009. Liberalism, Surveillance, and Resistance: Indigenous Communities in Western Canada, 1877-1927. Athabasca (AB): AU Press.

Snow AD, Benford RD. 2000. Framing Processes and Social Movements: An Overview and Assessment. Annual Review of Sociology 26: 611-39.

Snow AD, Benford RD. 1988. Ideology, Frame Resonance, and Participant Mobilization. From Structure to Action: Social Movement Participation Across Cultures. Greenwich (CT): JAI Press p. 197-217.

Snow AD, Vliegenthart R, Corrigall-Brown C. 2007. Framing the French Riots: A Comparative Study of Frame Variation. Social Forces 
2(86): 385-415.

Soja WE. 2010. Seeking Spatial Justice. Globalization and Community Series. Minneapolis (MN): University of Minnesota Press.

Stoler LA. 1995. Race and the Education of Desire: Foucault's History of Sexuality and the Colonial Order of Things. Durham (ON): Duke University Press.

TRC Final Report 2016. Volume 6 Reconciliation Report. [accessed Mar 22, 2016]. nctr.ca/assets/reports/Final\%20Reports/Volume_6_Reconciliation_English_Web.pdf . Accessed April 4, 2016. firstpeoplesofcanada.com/images/ firstnations/fp_maps/treaty_map_16qual.jpg.

Turner D. 1998. From Valladolid to Ottawa: The Illusion of Listening to Aboriginal People. In: Oakes J, et al., editors. Sacred Lands: Aboriginal World Views, Claims, and Conflicts. Edmonton (AB): University of Alberta Press. p. 53-68.

Turner D. 2000. Liberalism's Last Stand: Aboriginal Sovereignty and Minority Rights. In: Cook C, Lindau JD, editors. Aboriginal Rights and Self Government: The Canadian and Mexican Experience in North American Perspective, Montreal and Kingston (ON): McGill-Queen's University Press. p. 135-47.

UN. 1948. UNITED NATIONS GENERAL ASSEMBLY. Convention on the Prevention and Punishment of the Crime of Genocide. [Online]. Available: http://www.hrweb.org/legal/ genocide.html [March 2013]

UN Treaty Collection. 2016. Depository of Treaties. [online]. Available: https://treaties.un.org/ [June 2016].

Windschuttle K. 2001. The Fabrication of Aboriginal History. The New Criterion 20(1): 41-49.

Wolfe P. 2006. Settler Colonialism and the Elimination of the Native. Journal of Genocide Research 8(4): 387-409. 